\title{
A case of acute hepatitis associated with COVID-19 in a geriatric patient
}

\section{Geriatrik hastada COVID-19 ilişkili akut hepatit olgusu}

\author{
๑Muharrem Bayrak, ๑Kenan Çadırcı \\ Department of Internal Medicine, Erzurum Regional Training and Research Hospital, Health Sciences University, Erzurum, Turkey
}

Cite this article as / Bu makaleye atıf için: Bayrak M, Çadırcı K. A case of acute hepatitis associated with COVID-19 in a geriatric patient. J Med Palliat Care 2021; 2(3): 102-104.

\begin{abstract}
Coronavirus 2019 disease (COVID-19) is a deadly disease that causes 44 million positive cases and over 1 million deaths worldwide. COVID-19 is a disease in which respiratory tract infectious diseases such as fever, shortness of breath, and cough are observed more frequently. It has been observed to cause liver damage in literature studies in addition to respiratory symptoms. Our case is a 77-year-old male having no systemic disease except hypertension. Fever of $38.2^{\circ} \mathrm{C}$ for four days, pulse $84 / \mathrm{min}$, respiratory rate $18 / \mathrm{min}$, blood pressure $136 / 82 \mathrm{mmHg}$, and oxygen saturation on room air was measured $92 \%$ by pulse oximetry. The patient who had aspartate aminotransferase (AST) $753 \mathrm{IU} / \mathrm{L}$ and alanine aminotransferase (ALT) $683 \mathrm{U} / \mathrm{L}$ in the tests in the emergency room was admitted to the infectious diseases service because of acute liver damage and the positive result of the COVID-19 PCR-RT test performed in the emergency department. The diagnosis of acute hepatitis associated with COVID-19 was made in our case, after excluding other causes of elevated liver enzymes. We aimed to contribute to the literature by presenting our case.
\end{abstract}

Keywords: Coronavirus (COVID-19), acute hepatitis, infection

\section{ÖZ}

Koronavirüs 2019 hastalığı (COVID-19) dünya genelinde 44 milyon pozitif vaka ve 1 milyonun üzerine ölüme sebep olan ölümcül bir hastalıktır. COVID-19 ateş, nefes darlığı ve öksürük gibi solunum yolu enfeksiyon hastalıkları bulgularının daha sık izlendiği bir hastalıktır. Solunumsal semptomlarının yanında literatür çalışmalarında karaciğer hasarına yol açtığı görülmüştür. Vakamız 77 yaşında erkek, hipertansiyon haricinde herhangi bir sistemik hastalığı yoktu. Dört gündür başlayan $38,2^{\circ} \mathrm{C}$ ateş, nabız 84/dk, solunum sayısı 18/dk, tansiyon $136 / 82 \mathrm{mmHg}$, oda havasında oksigen saturasyonu pulse oksimetri ile ölçümü \%92'idi. Acil servisteki tetkiklerinde aspartat aminotransferaz (AST) 753 IU/L ve alanin aminotransferaz (ALT) 683 U/l olan hastanın akut karaciğer hasarı olması, acil serviste yapılan COVID-19 PCRRT testinde pozitif olması nedeniyle enfeksiyon hastalıkları servisine yatırıldı. Vakamızda karaciğer enzim yüksekliği yapan diğer nedenler dışlandıktan sonra COVID-19 ilişkili akut hepatit olgusu tanısı konuldu. Olgumuzu literatüre sunarak katkı sağlamayı amaçladık.

Anahtar kelimeler: Koranavirüs (COVID-19), akut hepatit, enfeksiyon

\section{INTRODUCTION}

Coronavirus 2019 disease (COVID-19) is a deadly disease that causes 44 million positive cases and over 1 million deaths worldwide (1). SARS-CoV-2 Angiotensin is known to use the converting enzyme 2 (ACE2) receptor. In COVID-19 infection via the ACE2 receptor on the cell surface, it causes more respiratory symptoms but also causes effects on the liver, heart, pancreas, and intestines (2). Even people who have not had any previous disease may have impaired liver function in COVID-19 infection. They found in studies conducted in China that there was a $14-50 \%$ deterioration in liver functions in healthy people in COVID-19 patients and people with predisposing liver diseases $(3,4)$. Liver damage of COVID-19 can occur by several mechanisms. The direct cytotoxic effect of the virus, the immune system in the liver, and the side effects of the drugs used in treatment can cause this damage. The virus causes overexpression in hepatocytes mediated by the ACE2 receptor. It initiates replication mechanisms in the cell with the ACE2 receptor and 
makes new viral RNA synthesis, release, and protein synthesis (5-7). COVID-19 ACE2 receptors have limited effects on hepatocytes. Therefore, this limitation may explain the development of viral hepatitis and the absence of changes in liver enzymes in every patient (8). Although the virus is thought to cause damage in hepatocytes via viral cytotoxicity and the immune system, the mechanism is not fully understood. In our case, we think that we aim to contribute to the literature as a rare case by diagnosing with acute hepatitis after the sudden increase in liver enzymes with COVID-19 infection and by eliminating other pathologies that would explain this in a person who did not have any known liver damage before.

\section{CASE}

Our case is a 77-year-old male and did not have any systemic disease except hypertension. He had been using valsartan/hydrochlorothiazide (160-12.5 mg) for 11 years. $38.2^{\circ} \mathrm{C}$ fever for four days, pulse $84 / \mathrm{min}$, respiratory rate $18 / \mathrm{min}$, blood pressure $136 / 82 \mathrm{mmHg}$, and oxygen saturation on room air was measured $92 \%$ by pulse oximetry. The lung examination of the patient was normal on the first day of the infection service. There was no icterus in the skin and mucous membranes. There was no hepatomegaly, lymphadenopathy, splenomegaly. In laboratory tests, hemoglobin $14 \mathrm{~g} / \mathrm{dL}$ (14.1-17.8), white blood cell (WBC) $7.09 \times 10^{3}\left(3.91-10.9 \times 10^{3}\right)$, platelet $285 \times 10^{3}\left(152-383 \times 10^{3}\right)$, serum reactive protein (CRP) $48.4 \mathrm{mg} / \mathrm{L}$ (0-5) mg/L), D-dimer $901 \mathrm{mgL}$ (0-500 mgL, procalcitonin $0.143 \mathrm{ng} / \mathrm{ml}(0-0.05 \mathrm{ng} / \mathrm{ml})$, fibrinogen 679 $\mathrm{mg} / \mathrm{dL}$ (200-400 mg/dL), INR: 1.01 (08.1.2), total serum bilirubin $0.5 \mathrm{mg} / \mathrm{dl}(0.2-1.0 \mathrm{mg} / \mathrm{dl})$, AST $753 \mathrm{u} / \mathrm{l}(0-40$ $\mathrm{u} / \mathrm{l})$, ALT $683 \mathrm{u} / \mathrm{l}(7-40 \mathrm{u} / \mathrm{l})$, gamma-glutamyl transferase (DDT) $26 \mathrm{u} / \mathrm{l}$ (7-50 u/l), alkaline phosphatase $74 \mathrm{u} / \mathrm{l}$ (46$116 \mathrm{u} / \mathrm{l})$, serum albumin $3.8 \mathrm{mg} / \mathrm{dl}$ (3.2-4.8 g/dl), ferritin $514 \mu \mathrm{g} / \mathrm{L}(30-400 \mu \mathrm{g} / \mathrm{L})$ (Table). No hepatosteatosis, thrombus, and other pathologies were observed in the abdominal and portal vein doppler ultrasonography. Viral hepatitis serological tests; hepatitis A, B, C, E, cytomegaly virus, Epstein-Barr virus, H1N1, and another respiratory virus panel were negative. Brucella serological tests were also found to be negative as a hepatitis agent. There was no growth in blood, urine, and sputum cultures. No pathology was found in thoracic tomography and echocardiography performed in terms of hypoxia and perfusion disorder. The autoimmune hepatitis panel was negative. Since the COVID-19 PCR-RT test performed in our case was positive, antiviral treatment Favipiravir $2 \times 1600$ mg loading and $2 \times 600 \mathrm{mg}$ maintenance (10 days), subcutaneous $60 \mathrm{mg} /$ day enoxaparin, acetylcysteine 900 $\mathrm{mg} /$ day treatment were started. On the second day of the patient, AST $544 \mathrm{u} / \mathrm{l}$, ALT $578 \mathrm{u} / \mathrm{l})$, alkaline phosphatase
$68 \mathrm{u} / \mathrm{l}$, oxygen saturation on room air was measured $93 \%$ by pulse oximetry, $37.2^{\circ} \mathrm{C}$ fever, pulse $76 / \mathrm{min}$, respiratory rate $16 / \mathrm{min}$, blood pressure $137 / 84 \mathrm{mmHg}$. On the $3^{\text {rd }}$ day of our case, AST $417 \mathrm{u} / \mathrm{l}$, ALT $519 \mathrm{u} / \mathrm{l}$ ), alkaline phosphatase $68 \mathrm{u} / \mathrm{l}$, oxygen saturation on room air was measured $95 \%$ by pulse oximetry, $36.9^{\circ} \mathrm{C}$ fever, pulse $76 / \mathrm{min}$, respiratory rate $16 / \mathrm{min}$, blood pressure 132/81 mmHg. The control COVID-19 PCR-RT test was negative on the $8^{\text {th }}$ day of the COVID-19 treatment of our patient. AST $52 \mathrm{u} / \mathrm{l}$, ALT $190 \mathrm{u} / \mathrm{l}$ ), alkaline phosphatase $77 \mathrm{u} / \mathrm{l}$, oxygen saturation on room air was measured $96 \%$ by pulse oximetry, $36.5^{\circ} \mathrm{C}$ fever, pulse $76 / \mathrm{min}$, respiratory rate $16 / \mathrm{min}$, blood pressure $128 / 83 \mathrm{mmHg}$. Our patient's AST decreased to $30 \mathrm{u} / \mathrm{l}$; ALT decreased to $73 \mathrm{u} /$ lon the $14^{\text {th }}$ day of the treatment. The change of liver enzymes in the treatment period is shown in Figure. Our patient, whose general condition was good and vital signs were stable, was discharged home. A written consent form was obtained for our patient to write the case.

\section{Table. Laboratory findings of COVID-19 positive case after} diagnosis and treatment

\begin{tabular}{|c|c|c|}
\hline & $1^{\text {st }}$ Day & $14^{\text {th }}$ Day \\
\hline Hemoglobin (g/dL) (14.1-17.8) & 14.3 & 14.8 \\
\hline White blood cell $\times 10^{3}(3.91-10.9)$ & 7.09 & 7.16 \\
\hline Platelet $\times 10^{3}(152-383)$ & 165 & 221 \\
\hline AST u/l (0-40) & $753^{*}$ & 30 * \\
\hline ALT u/l (7-40) & $683^{*}$ & $73^{*}$ \\
\hline Albumin mg/dl (3.2-4.8 g/dl) & 3.8 & 3,6 \\
\hline GGT u/l (7-50 iu/l) & 26 & 22 \\
\hline Alkaline phosphatase $\mathrm{u} / \mathrm{l}(46-116)$ & 74 & 77 \\
\hline Total bilirubin $\mathrm{mg} / \mathrm{dl}(0.2-1.0)$ & 0.5 & 0.42 \\
\hline CRP mg/L(0-5 ) & 48.4 & 3.4 \\
\hline D-dimer mgL (0-500) & 901 & 229 \\
\hline Procalcitonin ng/ml (0-0.05) & 0.143 & 0,04 \\
\hline Fibrinogen mg/dL (200-400) & 506 & 328 \\
\hline Ferritin $\mu \mathrm{g} / \mathrm{L}(30-400)$ & 459 & 358 \\
\hline INR & 1.09 & 1.11 \\
\hline S/D ABP mmHg & $136 / 82$ & $127 / 81$ \\
\hline $\mathrm{SpO}_{2}$ & $\% 92$ & $\% 96$ \\
\hline GFR $\left(\mathrm{ml} / \mathrm{dk} / 1.73 \mathrm{~m}^{2}\right)$ & 77 & 66 \\
\hline
\end{tabular}

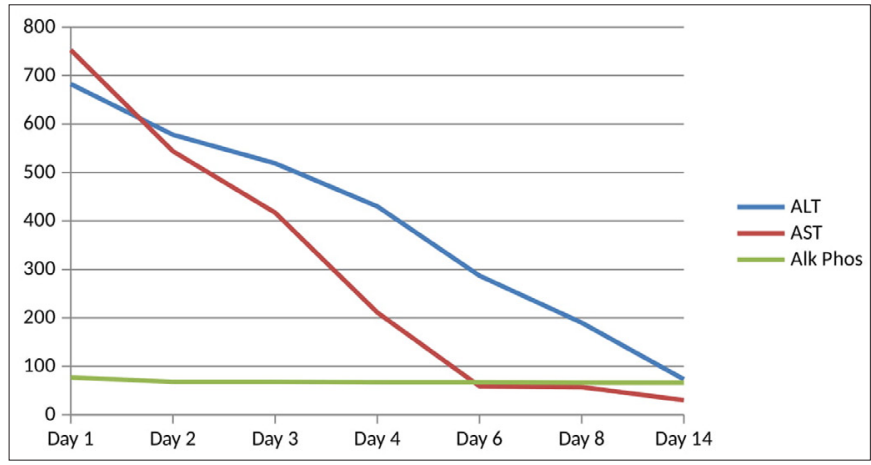

Figure. Changes in liver enzymes within days at the end of the diagnosis and treatment of the COVID-19 positive case. 


\section{DISCUSSION}

COVID-19 is a disease in which respiratory tract infectious diseases such as fever, shortness of breath, and cough are observed more frequently. COVID-19 infection causes more respiratory symptomsthrough the ACE2 receptor on the cell surface but also causes effects on the liver, heart, pancreas, and intestines (2). It was first shown in the literature that it caused some histopathological changes such as hepatocyte apoptosis, mitosis, and ballooning in the liver in liver biopsy performed in the viral RNA virus SARS coronavirus infection in 2002 (9). Liver biopsy performedin a case with MERS coronavirus in 2012 showed moderate portal inflammation and perivenular necrosis. An increase inthe patient's liver enzymes was observed (10). Wander et al. (11) presented the literature in 2020 a non-icteric COVID-19-associated acute hepatitis case after excluding other causes of a sudden increase in liver enzymes in a 57-year-old COVID-19 positive patient who had no liver pathology before. Our case was an older male patient, as in this case, there was no known liver pathology before and also all other etiological reasons that would increase liver enzymes were excluded as in the other case. A dramatic decrease in liver enzyme values was also observed in our patient in our follow-ups after COVID-19 treatment. We think that although Favipiravir treatment is a hepatotoxic agent and we use high doses, no additional increase in liver values was observed in our patient, which is a finding that supports COVID-19-related acute hepatitis in our patient. In the study of Lagana et al. (12), lobular lymphohistiocytic inflammation and apoptotic hepatocytes were observed in the liver biopsy performed in a patient with positive COVID-19 PCR test performed with complaints such as fever and shortness of breath on the 4th day after liver transplantation in a 6-month-old infant with biliary atresia and increased liver enzymes. and the patient was thought to have COVvID-19 associated hepatitis. In this case, the decrease in liver enzymes after treatment was similar to our case. We consider the patient's pediatric age group, bile duct pathology, and liver transplantation surgery as factors that differ from our case. We consider the absence of liver biopsy in our case as a limitation of our study.

\section{CONCLUSION}

COVID-19 infection is a disease that affects many systems other than the respiratory tract and causes systemic symptoms. We would like to emphasize the development of acute hepatitis, which is a rare finding of COVID-19 infection, and that COVID-19 may lead to acute liver damage while following this disease by presenting the COVID-19 related acute hepatitis case. Also, we aim to contribute to the literature by presenting the rare case of COVID-19 associated with acute hepatitis.

\section{ETHICAL DECLARATIONS}

Informed Consent: Written informed consent was obtained from all participants who participated in this study.

Referee Evaluation Process: Externally peer-reviewed.

Conflict of Interest Statement: The authors have no conflicts of interest to declare.

Financial Disclosure: The authors declared that this study has received no financial support.

Author Contributions: Article writing and editing: MB, KÇ. Table and graph drawing: MB.

\section{REFERENCES}

1. Johns Hopkins coronavirus resource center retrieved from https:// coronavirus.jhu.edu/data/mortality at $08.02 \mathrm{pm}$. 28.10.2020.

2. Téllez L, Martín Mateos RM. COVID-19 and liver disease: An update. Actualización en COVID-19 y enfermedad hepática. Gastroenterol Hepatol 2020; 43: 472-80.

3. Huang C, Wang Y, Li X, et al. Clinical features of patients infected with 2019 novel coronavirus in Wuhan, China. Lancet 2020; 395: 497-506.

4. Xu L, Liu J, Lu M, Yang D, Zheng X. Liver injury during highly pathogenic human coronavirus infections. Liver Int 2020; 40: 998-1004.

5. Bourgonje AR, Abdulle AE, Timens W, et al. Angiotensinconverting enzyme 2 (ACE2), SARS-CoV-2 and the pathophysiology of coronavirus disease 2019 (COVID-19). J Pathol 2020; 251: 228-48.

6. Feng G, Zheng KI, Yan QQ, et al. COVID-19 and Liver Dysfunction: Current Insights and Emergent Therapeutic Strategies. J Clin Transl Hepatol 2020; 8: 18-24.

7. Boregowda U, Aloysius MM, Perisetti A, Gajendran M, Bansal P, Goyal $H$. serum activity of liver enzymes is associated with higher mortality in COVID-19: a systematic review and meta-analysis. Front Med (Lausanne) 2020; 7: 431.

8. Tian S, Xiong Y, Liu H, et al. Pathological study of the 2019 novel coronavirus disease (COVID-19) through postmortem core biopsies. Mod Pathol 2020; 33: 1007-14.

9. Chau TN, Lee KC, Yao H, et al. SARS-associated viral hepatitis caused by a novel coronavirus: report of three cases. Hepatology 2004; 39: 302-10.

10. Alsaad KO, Hajeer AH, Al Balwi M, et al. Histopathology of Middle East respiratory syndrome coronovirus (MERS-CoV) infection - clinicopathological and ultrastructural study. Histopathology 2018; 72: 516-24.

11. Wander P, Epstein M, Bernstein D. COVID-19 presenting as acute hepatitis. Am J Gastroenterol 2020; 115: 941-2.

12.Lagana SM, De Michele S, Lee MJ, et al. COVID-19 associated hepatitis complicating recent living donor liver transplantation. Arch Pathol Lab Med 2020; 10.5858/arpa.2020-0186-SA. 